\title{
SIMULATION AND ANALYSIS OF AN INDUSTRIAL COLUMN SYSTEM OF BIOETHANOL DISTILLATION HEATED BY VAPOR DIRECT INJECTION
}

\author{
Luiz Mario de Matos Jorge ${ }^{I}$ \\ Patrícia Aparecida Polli ${ }^{2}$ \\ Douglas Junior Nicolin ${ }^{3}$ \\ Regina Maria Matos Jorge ${ }^{4}$ \\ Paulo Roberto Paraíso ${ }^{5}$ \\ Rubens Maciel Filho ${ }^{6}$
}

\begin{abstract}
Most commercial process simulators have its origin at the petrochemical industry and their use in other sectors depends on testing. In this context a model of an industrial column system of bioethanol distillation heated by direct injection of vapor was developed and implemented using the simulator Aspen HYSYS, which was compared with experimental data obtained in the industrial plant. The system basically consists of four columns heated by direct vapor injection and the model of the system was developed using this approach together with the simulation blocks for columns heated by reboilers available on Aspen HYSYS. For such a task it was admitted a null termal load for the reboiler and a direct vapor stream was added in the side of the column. Overall deviations between simulated values and those measured in the distillery were $2.3 \%$ for temperatures, $12.95 \%$ for concentrations, and $1.07 \%$ for bioethanol production in the industrial distillation system (IDS). The low values of the deviations obtained when comparing the data of the real process with simulated data indicate that IDS is well sized and the model implemented as well as the process simulator adopted can be used in the sugar-ethanol industry with distillation columns heated by direct injection of vapor.
\end{abstract}

Keywords: Distillation columns; Process simulation; Aspen HYSYS; Bioethanol.

\footnotetext{
${ }^{1}$ PEQ - UEM, Chemical Engineering Graduate Program, Chemical Engineering Department, State University of Maringá (UEM). E-mail: lmmj@ deq.uem.br.

${ }^{2}$ PEQ - UEM, Chemical Engineering Graduate Program, Chemical Engineering Department, State University of Maringá (UEM). E-mail: pg50975@ deq.uem.br.

${ }^{3}$ PEQ - UEM, Chemical Engineering Graduate Program, Chemical Engineering Department, State University of Maringá (UEM). E-mail: douglas.nicolin@gmail.com.

${ }^{4}$ PEQ - UEM, Chemical Engineering Graduate Program, Chemical Engineering Department, State University of Maringá (UEM). E-mail: rjorge@ ufpr.br.

${ }^{5}$ PEQ - UEM, Chemical Engineering Graduate Program, Chemical Engineering Department, State University of Maringá (UEM). E-mail: paulo@ deq.uem.br.

${ }^{6}$ School of Chemical Engineering, State University of Campinas (Unicamp). E-mail: maciel@ feq.unicamp.br
} 


\section{INTRODUCTION}

Political instability of main oil-
producing countries, environmental factors, or even the forecasted depletion of petroleum are some of the reasons why the world has turned its attention to the production of bioethanol as a source of renewable and sustainable energy. Brazil has great advantage in this process as it has a vast territory and favorable weather conditions, where technology for ethanol producing from sugarcane is already consolidated.

These beneficial aspects cause positive socioeconomic impacts for the country such as employment and income generation, internal development, foreign exchange increase as a result of exports and the possibility to complement the increasing energy demand, dependent on petroleum and natural gas (Oliveira et al., 2012; Lima et al., 2010). In 2012 the production of bioethanol fuel in Brazil reached 5,577 millions of gallons (21.11 million $\mathrm{m}^{3}$ ). It is approximately $96 \%$ of the total South American production, which was 5,800 millions of gallons or 21.96 million $\mathrm{m}^{3}$ in the same period (RFA, 2013). When world bioethanol fuel production is taken into consideration, the American continent is in first place with a total of 19,568 millions of gallons (74.07 million $\mathrm{m}^{3}$ ) produced in 2012. For the same year, Europe is in second place with 1,139 millions of gallons (4.31 million $\mathrm{m}^{3}$ ) of bioethanol produced and Asia comes third with 952 millions of gallons (3.6 million $\mathrm{m}^{3}$ ) (RFA, 2013).

It is worth mentioning that other raw material sources for the production of bioethanol have been studied in the past years such as lignocellulose agricultural wastes (Sarkar et al., 2012), banana pulp and peel (Souza et al., 2012), coffee industry rejects, coffee grounds (Kwon et $a l .$, 2013) among others.

The sugar-ethanol industry has increased rapidly making the use of commercial process simulators necessary with the aim of providing fast responses to major challenges involving production increase, which is directly related to the project and fast installation of new industrial units and the optimization and expansion of existing plants. Generally, bioethanol distillation columns from most of the current industrial plants are heated by direct injection of vapor and it was difficult to find works in literature which present simulation results using data obtained directly from the industrial plants. Most of the simulation works found in literature simulate distillation columns heated by reboilers and the simulations are mainly developed to describe petrochemical processes (Kim, 2006; Luyben, 2009, Ravagnani et al., 2010; Dias et al., 2011; Kiss and Suszwalak, 2012).

Main commercial process simulators as Aspen HYSYS has its origin in the petrochemical industry and their use in other sectors depends on the validation of thermodynamic packages and the adaptation or development of new simulation blocks.

Process simulator Aspen HYSYS has been used in technical and economic analysis of several processes. Those include biodiesel production from vegetable oils (Apostolakou et al., 2009; Santana et al., 2009), control setting evaluation of a depropanizing process (Chawla and Rangaiah, 2008), the study of extractive distillation processes of the mixture isobutyl isobutanol-acetate at an industrial plant (Muñoz et al., 2006), simulation of sugarcane juice evaporation system for bioethanol production (Jorge $e t$ al., 2010), conceptual processes involving acetone-methanol, methyl-methanol acetate, and methanol-chloroform binary systems (Langston et al., 2005).

Melo et al. (2000) developed a simulation and optimization study of a conceptual unit for anhydrous ethanol production by extractive distillation in a ternary system: ethanol-water-ethylene glycol. It was conducted by the process simulator HYSIM using the UNIQUAC (Universal Quasi Chemical) 
thermodynamic model to calculate activities (Abrams and Prausnitz, 1975).

The same thermodynamic model (UNIQUAC) was used by Werle et al. (2007) to carry out an energy evaluation of a binary mixture ethanol-water distillation column on a pilot scale using Aspen HYSYS. In turn, Marquini et al. (2007) compared results obtained from simulations in ethanol distillation columns using the thermodynamic models NRTL (Non-Random Two Liquid), UNIQUAC, and Van Laar and observed that the model NRTL led to better results (Renon and Prausnitz, 1968; Abrams and Prausnitz, 1975; Peng, 2010).

In addition to aspects involved in the evaluation of thermodynamic properties, modeling, simulation and validation, energy consumption involved in the heating of distillation columns is highly significant. Process simulation is also a very important tool in this regard (Camargo, 1990).

In an industrial distillation process, fermented wine from fermentation tanks goes through a distillation process in order to obtain hydrous ethanol with $93.2 \pm 0.6^{\circ}$ INPM. The wine consists of a complex mixture predominantly including ethanol and water. In this context, a simplified model of a binary industrial distillation system was developed and solved with Aspen HYSYS. The results obtained adequately represented the thermal and mass behavior of the system after considering in the software that the distillation columns were heated by direct injection of vapor and not by reboilers. This was the suggestion proposed to reflect the manner that distillation columns are heated in industrial plants. The results obtained with the model were compared with data from an industrial plant in order to evaluate if the approach presented in this work could be used to represent the real bioethanol distillation process.

\section{INDUSTRIAL DISTILLATION SYSTEM (IDS)}

The hydrous ethanol distillation system from COCAFÉ (Figure 1) consists of 5 distillation columns: A, A1, B, B1, and $\mathrm{D}$, the characteristics of which are presented in Table 1 and their arrangement shown in Figure 2. In this system, the wine is heated to near its boiling temperature before being fed on the top of column A1. Such heating is carried out in 3 stages. Initially the wine goes through the top condenser (E) from column B where it acts as a coolant. Then it passes through $\mathrm{K}$ heat exchangers, heated by the vinasse at the bottom of column A, and completes its heating process in the $\mathrm{K} 1$ heat exchangers heated by steam in order to reach near boiling temperature.

Table 1. Main characteristics of the distillation column system

\begin{tabular}{|c|c|c|c|c|c|}
\hline \multirow[b]{2}{*}{ Column } & \multirow{2}{*}{$\begin{array}{l}\text { Diameter } \\
(\mathrm{m})\end{array}$} & \multirow{2}{*}{$\begin{array}{l}\text { Height } \\
\text { (m) }\end{array}$} & \multicolumn{3}{|c|}{ Tray characteristics } \\
\hline & & & Amount & $\begin{array}{c}\text { Spacing } \\
(\mathrm{m})\end{array}$ & Type \\
\hline A1 & 3.0 & 2 & 4 & 0.50 & $\begin{array}{c}\text { Bubble- } \\
\text { Cap }\end{array}$ \\
\hline A & 3.6 & 16 & 22 & 0.65 & $\begin{array}{l}\text { Valve } \\
\text { trays }\end{array}$ \\
\hline B & 3.3 & 16 & 45 & 0.35 & $\begin{array}{l}\text { Valve } \\
\text { trays }\end{array}$ \\
\hline B1 & 3.3 & 7 & 16 & 0.35 & $\begin{array}{c}\text { Bubble- } \\
\text { Cap }\end{array}$ \\
\hline $\mathrm{D}$ & 1.5 & 1.7 & 6 & 0.24 & $\begin{array}{c}\text { Bubble- } \\
\text { Cap }\end{array}$ \\
\hline
\end{tabular}




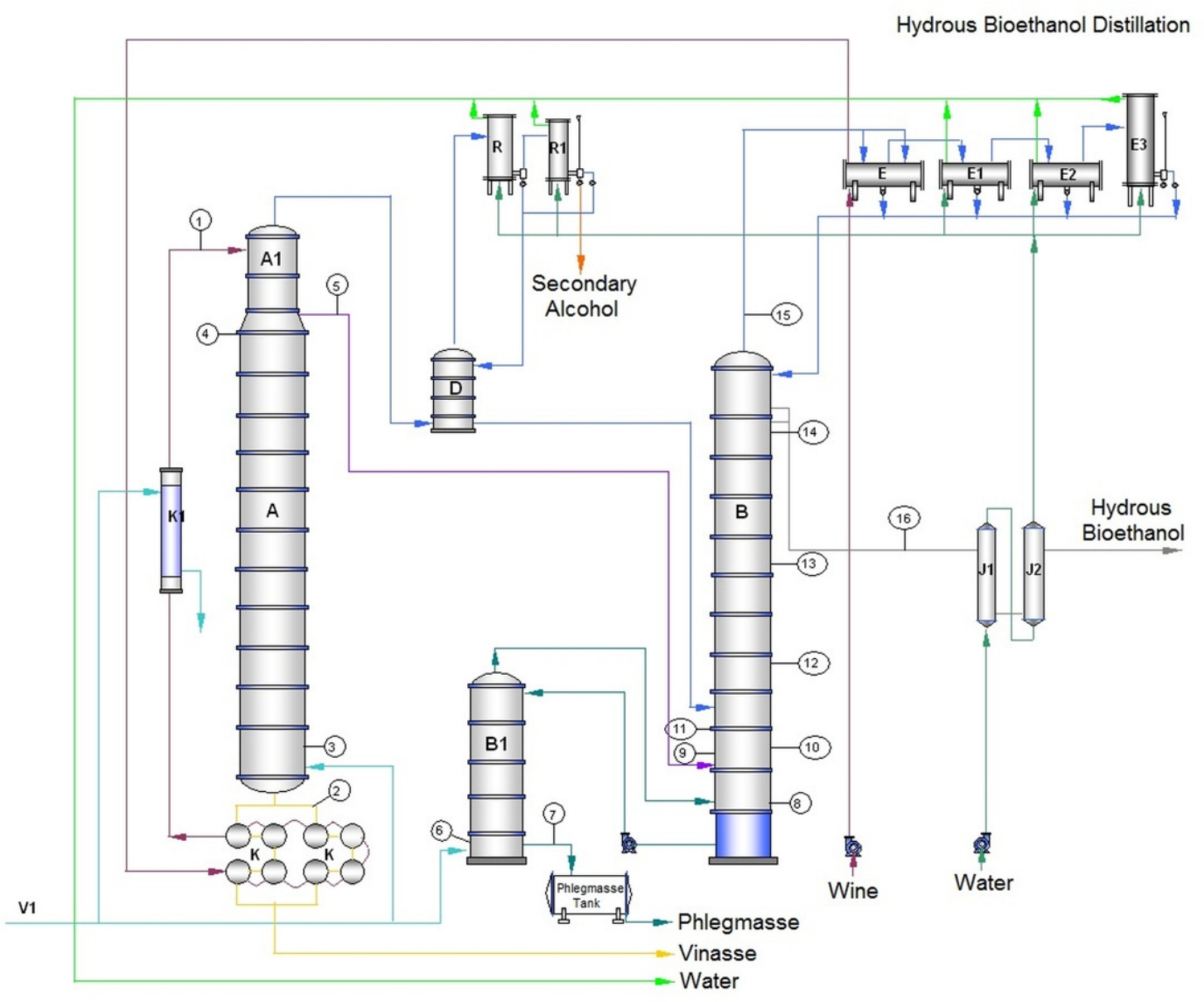

Figure 1. Distillation System scheme from COCAFÉ.

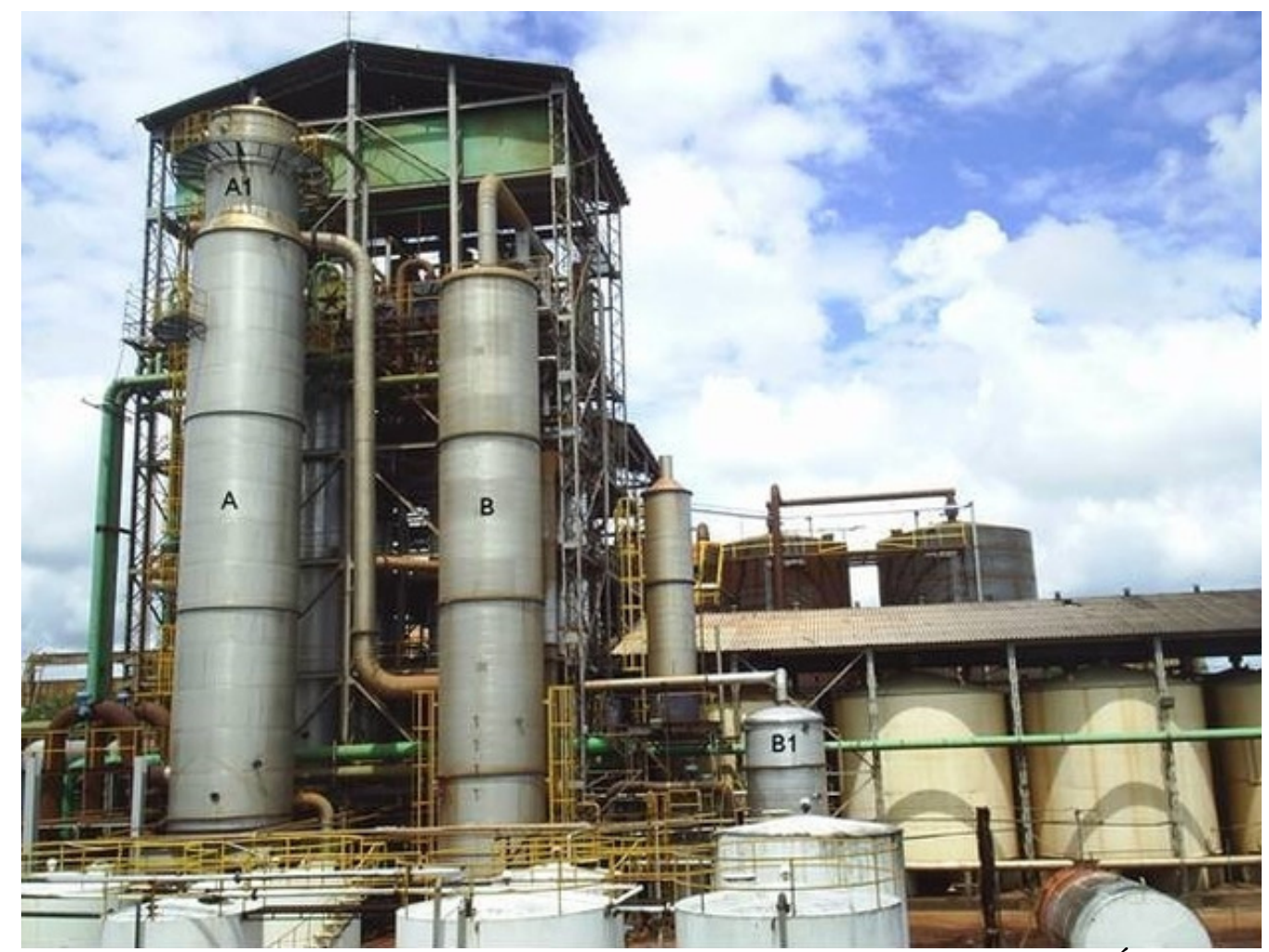

Figure 2. Distillation Columns of the industrial plant of COCAFÉ. 
Column A1 is aimed at separating more volatile substances and possible solubilized gases from the wine in the feed stream. Wine is fed in the top of column A1 and descends tray by tray towards column A (wine depletion column). During this route, an ascending gaseous stream is generated, rich in more volatile components and non-condensable gases that move on to column D (head concentration column).

Column D aims to increase the concentration of undesirable volatile components to the maximum facilitating extraction of condensable secondary compounds and non-condensable gases. Aldehydes, ketones, esters, and organic acids are among those secondary compounds. Stream from the bottom of column D contains low content of ethanol and is conducted to column B. In turn, top stream is conducted to condensers $\mathrm{R}$ and $\mathrm{R} 1$, from where non-condensable gases are removed in a purging process known as degassing, while the liquid stream consisting of condensed vapors returns to column D as a total reflux, or is partly removed from the system as secondary alcohol.

From the bottom of column A, a liquid stream called vinasse exits with maximum ethanol concentration of $0.016^{\circ} \mathrm{INPM}$ (mass percentage). Between columns $\mathrm{A}$ and $\mathrm{A} 1$ a stream rich in ethanol known as phlegm exits (30 to $40{ }^{\circ} \mathrm{GL}$ ) and is immediately admitted above the first tray of column B. Column A heating is carried out by direct injection of saturated vapor $(\mathrm{V} 1)$ at $1.7 \mathrm{kgf} / \mathrm{cm}^{2}$ abs.

Column $B$ is aimed at concentrating the phlegm stream from column A up to $93.2 \pm 0.6^{\circ} \mathrm{INPM}$, which is the amount required to commercialize hydrous ethanol fuel. From the top of this column alcoholic vapors exit, which are condensed in condensers E, E1, E2, and, $\mathrm{E} 3$, cooled by wine (E) and water. Condensed vapors return to the top of column B in total reflux. Hydrous ethanol is removed at the $42^{\text {nd }}$ tray and is cooled in the heat exchangers $\mathrm{J} 1$ and $\mathrm{J} 2$, while the bottom product is sent to column B1 (column of phlegm depletion).

Alcoholic vapors are conducted from the top of column B1 to the bottom of column B whilst a liquid stream named phlegmasse is removed essentially free of ethanol from the bottom of column B1. The entire heating system of distillation columns is performed by direct injection of saturated vapor (V1) at the bottom of columns B1 and A.

Data used in simulations refer to the capacity of COCAFÉ distillery to process 250 tons of sugarcane per hour for production of hydrous ethanol fuel up to $450 \mathrm{~m}^{3} /$ day.

\section{COLLECTING PROCESSING DATA}

To develop this work, temperatures, pressures, concentrations, and flow rates were measured at the points indicated in Figure 1 and Table 2.

Table 2. Variables measured in the process

\begin{tabular}{c|c}
\hline & Sampling points \\
\hline Temperature $\left({ }^{\circ} \mathrm{C}\right)$ & $1,2,3,4,5,10$, \\
& 11,16 \\
\hline Pressure $\left(\mathrm{kgf} \mathrm{cm}^{-2}\right)$ & $1,3,5,6,8,15$ \\
\hline $\begin{array}{c}\text { Ethanol concentration } \\
(\% \text { mass })\end{array}$ & $1,2,5,7,9,12$, \\
$13,14,16$ \\
\hline Flow $\left(\mathrm{kg} \mathrm{h}^{-1}\right)$ & 1,16 \\
\hline
\end{tabular}

Temperature measurements in the wine feed (point 1) in trays 1 and 22 from column A (points 3 and 2) and trays 6 and 8 from column B (points 10 and 11) were performed visually by means of bimetal thermometers and confirmed by the supervising system of the plant that provides temperatures indicators (PT-100) installed at the same points. Additionally thermometers were installed at points 2, 5, and 16 in order to measure temperature of 
vinasse, phlegm, and ethanol outlet stream respectively.

Operating pressures in the columns were measured at the bottom of columns A, B1, and B (points 3, 6, and 8) and at the top of columns A and B (points 5 and 15) by installing barometric bottles while wine feed pressure was assessed through a Bourdon manometer installed in the line.

All ethanol concentrations were determined at the industrial laboratory of the plant using an Anton Paar digital densimeter, model DMA 4500, from liquid samples collected in the feed streams of wine, vinasse, phlegmasse, and hydrous ethanol (points 1, 2, 7, and 16), trays $4,15,28$, and 43 in column B (points 9, 12, 13, and 14), and phlegm (point 5). In order to prevent changes in concentration prior to packaging, ethanol samples removed from trays in column B were cooled using a portable heat exchanger. Phlegm samples (vapor phase) were condensed by a tray heat exchanger installed in the line.

Wine flow was determined by means of a Conault magnetic flowmeter, model IFS 4000 KCIFC-010KD, installed in the wine feed stream (point 1), whereas hydrous ethanol flow in the system outlet (point 16) was evaluated through rotameters installed in the line.

\section{MODELING DISTILLATION SYSTEM USING ASPEN HYSYS}

The commercial process simulator Aspen HYSYS has several blocks of operations with columns that can be used to compose a model of distillation column system, with a reboiler at the bottom and condenser at the top in its classic form, and in several other configurations with or without reboiler and/or condenser. The challenge is to properly choose the blocks that will compose the distillation system model along with the adoption of simplified assumptions that lead to satisfactory results.

For purposes of modeling the current distillation system at COCAFÉ, the model presented in Figure 3 was proposed. In this model columns $\mathrm{A}$ and A1 and columns B and B1 are addressed jointly as two columns of equivalent conventional distillation, A-A1 and B-B1, with total reflux at top condensers and direct injection of vapor in the reboilers of columns A-A1 (V1-A) and B-B1 (V1-B).

The entire heating of the distillation columns in the system studied is provided by direct injection of vapor at the bottom of columns A and B1. To ensure the direct injection of vapor of the columns in the models, the thermal loads named Energy 2 and Energy 4 were fixed to $0 \mathrm{~kJ} / \mathrm{h}$. Since they represent the reboilers in the model, they are being eliminated of the distillation system when they are nullified. Thus, the heating of the columns are made solely by vapor streams V1-A (in column A-A1) and V1-B (in column B-B1).

A binary mixture ethanol-water was assumed and the NRTL thermodynamic model was adopted to determine activities of the liquid phase and efficiencies of trays in columns $\mathrm{A}$, $\mathrm{B} 1$, and $\mathrm{B}$ equal to 65,60 , and $50 \%$, respectively, as recommended by Marquini (2007). In addition, an ideal behavior was considered for the vapor phase due to the low pressure values involved in this process. 


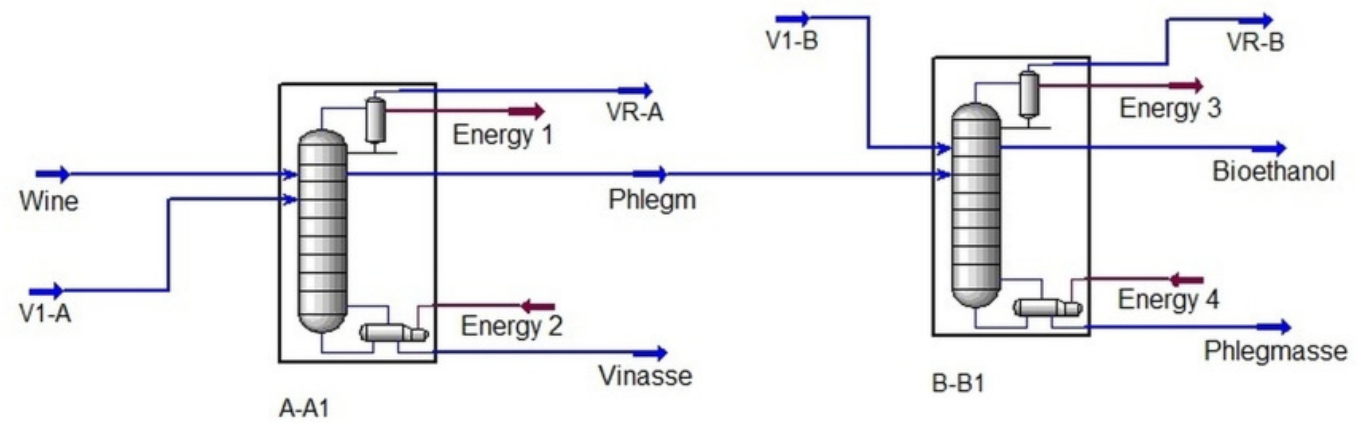

Figure 3. IDS model according to Aspen HYSYS

\section{RESULTS}

Simulations carried out for six campaigns of IDS operations with input data are shown in Table 3.

Table 3: Operational parameters used in simulations

\begin{tabular}{c|c|c|c|c|c|c|c}
\hline Measurement & Unit & \multicolumn{7}{c}{ Campaign } \\
\cline { 3 - 8 } & $\mathbf{1}$ & $\mathbf{2}$ & $\mathbf{3}$ & $\mathbf{4}$ & $\mathbf{5}$ & $\mathbf{6}$ \\
\hline Wine flow & $\mathrm{m}^{3} / \mathrm{h}$ & 203.93 & 201.57 & 189.86 & 209.41 & 219.98 & 199.5 \\
\hline Wine temperature & ${ }^{\circ} \mathrm{C}$ & 91.29 & 95.12 & 94.19 & 94.92 & 94.97 & 94.92 \\
\hline $\begin{array}{c}\text { Wine Ethanol Mass } \\
\text { Fraction }\end{array}$ & $\%$ & 6.71 & 6.28 & 5.3 & 5.6 & 5.3 & 6.06 \\
\hline $\begin{array}{c}\text { Pressure at the bottom } \\
\text { of column A }\end{array}$ & $\begin{array}{c}\mathrm{kgf} / \mathrm{cm}^{2} \\
\mathrm{Abs}\end{array}$ & 1.642 & 1.631 & 1.638 & 1.64 & 1.644 & 1.633 \\
\hline $\begin{array}{c}\text { Pressure at the top of } \\
\text { column A }\end{array}$ & $\begin{array}{c}\mathrm{kgf} / \mathrm{cm}^{2} \\
\mathrm{Abs}\end{array}$ & 1.455 & 1.436 & 1.462 & 1.452 & 1.465 & 1.462 \\
\hline $\begin{array}{c}\text { Pressure at the bottom } \\
\text { of column B }\end{array}$ & $\begin{array}{c}\mathrm{kgf} / \mathrm{cm}^{2} \\
\mathrm{Abs}\end{array}$ & 1.448 & 1.437 & 1.443 & 1.472 & 1.440 & 1.445 \\
\hline $\begin{array}{c}\text { Pressure at the top of } \\
\text { column B }\end{array}$ & $\begin{array}{c}\mathrm{kgf} / \mathrm{cm}^{2} \\
\mathrm{Abs}\end{array}$ & 1.160 & 1.215 & 1.220 & 1.224 & 1.260 & 1.142 \\
\hline $\begin{array}{c}\text { Concentration of } \\
\text { ethanol produced }\end{array}$ & \begin{tabular}{c}
${ }^{\circ} \mathrm{INPM}$ \\
\hline
\end{tabular} & 93.40 & 93.30 & 93.83 & 93.63 & 93.44 & 94.16 \\
\hline
\end{tabular}

For all simulations, qualitative behavior of concentration profiles and temperature in the columns was similar. For purposes of illustration and analysis, temperature and concentration profiles simulated and measured in the plant are shown in Figures 4 to 7 relating to campaign 1 (Table 3). In Figures 4 and 5, the first 22 trays refer to column A and the 4 subsequent ones correspond to column A1. In Figures 6 and 7, the first 16 trays relate to column $\mathrm{B} 1$ and the subsequent ones correspond to column B.

The analysis of temperature and concentration profiles along the trays of column A and A1 (Figures 4 and 5) shows that both temperature and ethanol concentration remained constant near the top of column A1 (trays 24 to 26). Following this region ethanol 
concentration in liquid as well as in vapor phase decreases continuously approaching each other and tending to zero at the bottom of column $\mathrm{A}$, thus requiring a continuous increase in temperature from the top to the bottom due to increased water content and pressure in the column (Table 3). Estimates of the model implemented with Aspen HYSYS and process measurements agreed well indicating that the strategy adopted was satisfactory.

As for the equivalent column AA1, concentration and temperature profiles predicted by Aspen HYSYS for the equivalent columns B-B1 are consistent with experimental data (Figures 6 and 7) indicating that the model implemented for these columns is also satisfactory. Temperature profile along column B-B1 tends to decrease from the top to the bottom of the column (Figure 6) showing temperature peak at the phlegm feed point, tray 1 of column B (tray 17 of equivalent column B-B1).

Below the feed tray of the equivalent column B-B1 (tray 17) ethanol depletion occurs, leading to concentration values which tend to zero in both phases at the bottom of column B1, as desired.

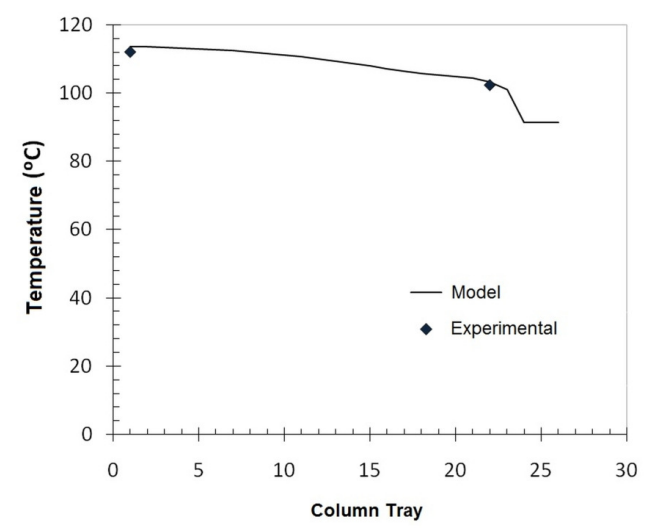

Figure 4: Temperature profile column AA1 - simulation 1.

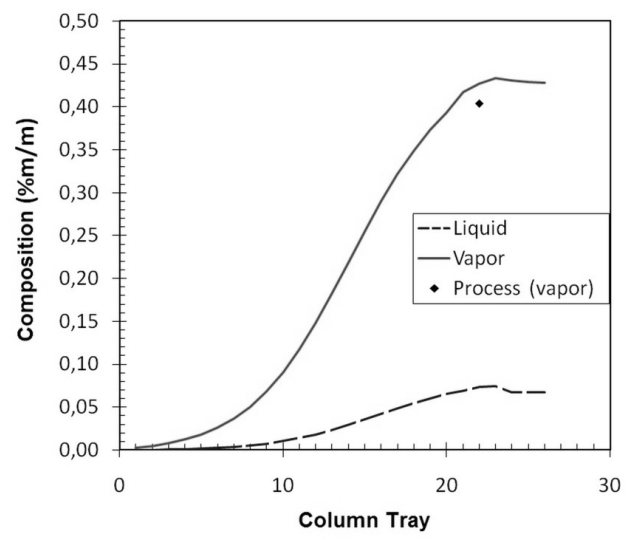

Figure 5: Ethanol concentration profiles column A-A1 - simulation 1.

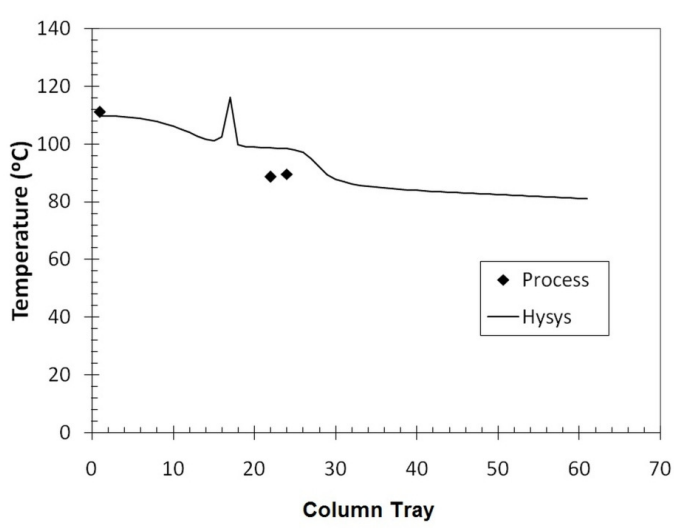

Figure 6: Temperature profiles column B-B1 - simulation 1.

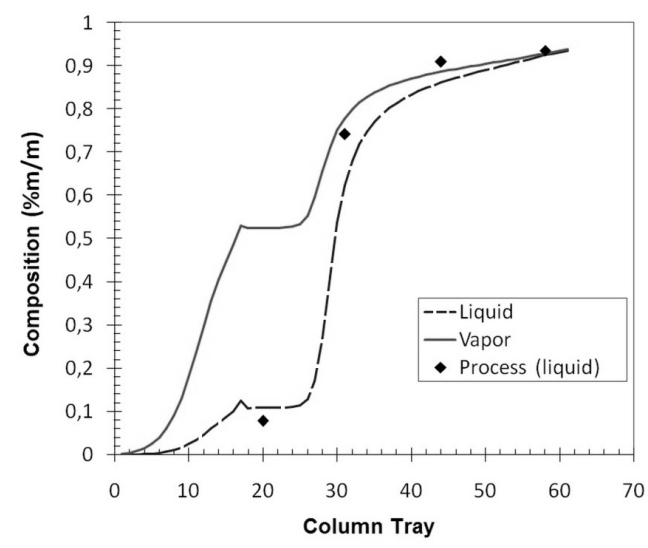

Figure 7: Ethanol concentration profiles column B-B1 - simulation 1.

Above the feed tray (column B) ethanol concentration takes place. In the region just above the feed point, trays 18 to 24 of the equivalent column B-B1, differences between ethanol concentrations in liquid and vapor phases 
remain practically constant. By analyzing the behavior in the feed tray from B-B1 equivalent column (tray 18) it is clear that the phlegm coming from the equivalent column $\mathrm{A}-\mathrm{A} 1$, is $17^{\circ} \mathrm{C}$ above the operation temperature on the neighborhood of this point (Figure 6), imposing small oscillation in the composition of the liquid and the vapor present in this tray (Figure 7). They tend to zero near the top showing the formation of an azeotropic mixture. From this point on it is not possible to separate ethanol by simple distillation. Simulation shows that the azeotrope tends to be formed close to the top of column B, and this reveals that IDS is well sized to the current operational conditions.

To evaluate the overall quality of the model IDS developed with Aspen HYSYS, the mean absolute deviation was defined and is represented by Equation 1 (temperature) and Equation 2 (concentration).

$$
\begin{aligned}
|\bar{d} \%|_{T} & =\frac{\sum_{i}\left(\frac{\left|T_{\text {exp }}^{i}-T_{\text {calc }}^{i}\right|}{T_{\text {exp }}^{i}}\right)}{n} \cdot 100, \quad i=1, \ldots, n \\
|\bar{d} \%|_{X} & =\frac{\sum_{i}\left(\frac{\mid X_{\text {exp }}^{i}-X_{\text {calc }}^{i}}{X_{\text {exp }}^{i}}\right)}{n} \cdot 100, \quad i=1, \ldots, n
\end{aligned}
$$

The mean absolute deviation for temperature is $3.89 \%$ and $11.60 \%$ for concentration from the concentration and temperature results obtained for simulation 1 (Figures 4 to 7). Only the result obtained for tray 4 of column B (tray 20 in Aspen HYSYS) showed different value from what was expected, with percentage deviation of $39 \%$.

Figures 8 and 9 show overall mean absolute deviations of temperatures and concentrations obtained from simulations of six campaigns evaluated (Table 3). For most points, temperature presented lower overall mean absolute deviation $(2.27 \%)$ than concentration $(12.61 \%)$.
Temperature and concentration deviations of simulation 1 are shown in the same order of magnitude as the overall absolute deviations (Figure 8 and 9) indicating that Aspen HYSYS properly represented all six tests carried out in the plant under distinct operational conditions and days.

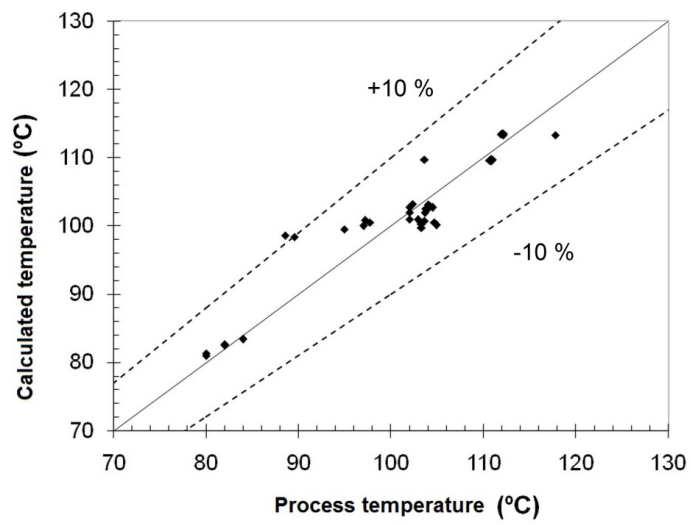

Figure 8: Overall temperature deviations.

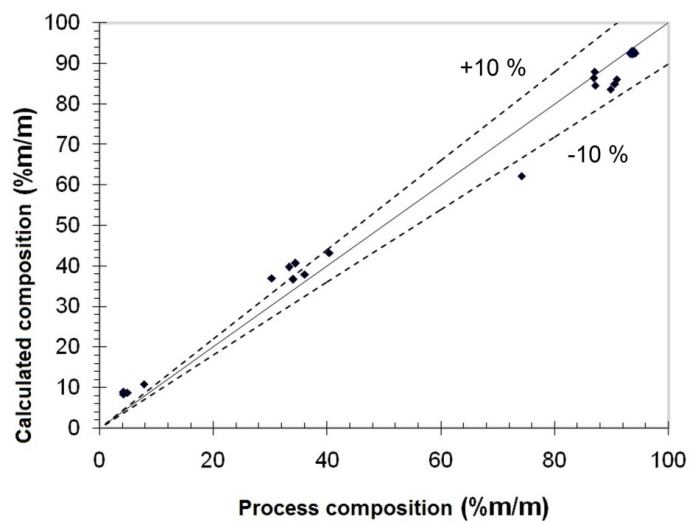

Figure 9: Overall deviations of ethanol concentration.

Expected and simulated values of hydrous ethanol production as well as percentage deviations in relation to the expected value for the six campaigns evaluated are found in Table 4. Production achieved is in accordance with expected values. Most values present deviations below $1.5 \%$ with mean deviation of $1.07 \%$.

Given the results obtained, it is possible to state that the model IDS deployed in Aspen HYSYS satisfactorily represented the industrial system under 
study and can be applied to the simulation of distillation column systems in the sugar-ethanol industry.

Table 4: Percentage absolute deviation of ethanol production for six campaigns

\begin{tabular}{cccc} 
Simulation & $\begin{array}{c}\text { *Expected } \\
\text { production } \\
\left(\mathrm{m}^{3} / \mathrm{h}\right)\end{array}$ & $\begin{array}{c}\text { Simulated } \\
\text { Productio } \\
\mathrm{n}\left(\mathrm{m}^{3} / \mathrm{h}\right)\end{array}$ & $\begin{array}{c}\text { Deviation } \\
(\%)\end{array}$ \\
\hline 1 & 17.855 & 17.900 & 0.25 \\
2 & 15.947 & 16.593 & 4.05 \\
3 & 13.282 & 13.127 & 1.17 \\
4 & 15.431 & 15.329 & 0.66 \\
5 & 15.303 & 15.282 & 0.14 \\
6 & 15.802 & 15.827 & 0.16
\end{tabular}

Calculated from mass balances per component (ethanol) throughout IDS.

\section{CONCLUSIONS}

The model of bioethanol industrial distillation system (IDS) used in Aspen HYSYS satisfactorily represented the behavior of the plant under study, indicating that the simulation of the system of distillation columns heated by direct injection of vapor was properly obtained, assuming a null thermal load in the reboiler and adding a side stream to vapor injection in the usual block of distillation columns simulator. Overall absolute deviations were $2.3 \%$ for temperatures, $12.95 \%$ for concentrations, and $1.07 \%$ for ethanol production in the industrial distillation system.

IDS is well sized for the current operational conditions and bioethanol production.

Considering that the process simulator Aspen HYSYS has its origin at the petrochemical industry, this study contributes to show the utility of this tool in sugarcane-bioethanol distilleries, even if a system can be satisfactorily represented by the ethanol/water binary mixture.

\section{REFERENCES}

ABRAMS, D. S., PRAUSNITZ, J. M., Statistical Thermodynamics of Liquid Mixtures: A New Expression for the Excess Gibbs Energy of Partly or Completely Miscible Systems. 1975. AIChE J., 21(1), 116-128.

APOSTOLAKOU, A. A., KOOKOS, I., K., MARAZIOTI, C. \& ANGELOPOULOS, K. C. 2009. Technoeconomic analysis of biodiesel production process from vegetable oils. Fuel Processing Technology, 90, 7 - 8, 1023 1031.

CAMARGO, C. A. 1990 Conservação de energia na indústria do açúcar e do álcool, São Paulo, IPT.

CHAWLA, I. \& RANGAIAH G. P. 2008, Evaluation of control configurations for a despropaniser. Chemical Engineering Research and Design, 86, 977-988.

DIAS, M. O. S., MODESTO, M., ENSINAS, A. V., NEBRA, S. A., MACIEL FILHO, R. \& ROSSELL, C. E. V. 2011. Improving bioethanol production from sugarcane: evaluation of distillation, termal integration and cogeneration systems. Energy, 36, 6, 3691 - 3703.

JORGE, L. M. M., RIGHETTO, A. R., POLLI, P.A., SANTOS, O. A. A. \& MACIEL FILHO, R. 2010. Simulation and analysis of a sugarcane juice evaporation system. Journal of Food Engineering, 99, 3, 351 - 359.

KIM, Y. 2006. A new fully thermally coupled distillation column with postfractionator. Chemical Engineering and Processing: Process Intensification, $45,4,254-263$.

KISS, A. A. \& SUSZWALAK, D. J.-P. C. 2012. Enhanced bioethanol dehydration by extractive and azeotropic distillation in 
dividing-wall columns. Separation and Purification Technology, 86, 70 - 78.

KWON, E. E., YI, H. \& JEON, Y. J. 2013. Sequential co-production of biodiesel and bioethanol with spent coffee grounds. Bioresource technology,136, 475 -480 .

LANGSTON, P., HILAL, N., SHINGFIELD, S. \& WEBB, S. 2005. Simulation and optimization of extractive distillation with water as solvent. Chem. Eng. Process, 44, 3, 345 - 351.

LIMA, M. A. P., LEAL, M. R. L. V. \& CORTEZ, L. A. B. 2010. Produção sustentável em larga escala de etanol de cana-de-açúcar no Brasil. Parceria Estratégica , 15, 31, 259 - 264.

LUYBEN, W. 2009. Control of a column/pervaporation process for separating the etanol/water azeotrope. Industrial \& Engineering Chemistry Research, 48, 7, 3484 - 3495.

MARQUINI, M. F. 2007 Análise de um sistema de colunas de destilação. Tese de Doutorado, Universidade Estadual de Maringá

MELO, D. N. C., FOSSY, M. F., COSTA, N. A. \& BRITO, R. P. Simulação e otimização da destilação extrativa para produção de etanol anidro: integração energética como alternativa de economia de energia. CONGRESSO BRASILEIRO DE ENGENHARIA QUÍMICA, 13., 2000, Águas de São Pedro, Brasil.

MUÑOZ, R., MONTÓN, J. B., BURGUET, M. C. \& DE LA TORRE J. 2006. Separation of isobutyl alcohol and isobutyl acetate by extractive distillation and pressure-swing distillation: Simulation and optimization. Separation and Purification Technology, 50, 2, 175 183.
OLIVEIRA, T. B. A., SELIG, P. M., BARBOSA, V. M., CAMPOS, L. M. S., BORNIA, A. C. \& OLIVEIRA, M. W. 2012. Tecnologia e custos de produção de cana-de-açúcar: um estudo de caso em uma propriedade agrícola. Latin American Journal of Business Management, 3, 1, $150-172$.

PENG, D. Y. 2010. Extending the Van Laar Model to Multicomponent Systems. The Open Thermodynamics Journal, 4, $129-140$.

RAVAGNANI, M. A. S. S., REIS, M. H. M., MACIEL FILHO, R. \& WOLFMACIEL, M. R. 2010. Anhydrous ethanol production by extractive distillation: A solvent case study. Process Safety and Environmental Protection , 88, $1,67-73$.

RENON, H., PRAUSNITZ, J. M. 1968. Local Compositions in Thermodynamic Excess Functions for Liquid Mixtures. AIChE J., 14(1), S.135-144,

RFA [Internet]. Washington DC: Renewable Fuel Associations Statistics, Ethanol Industry Overview 2013. [updated 2012, cited 2013 Jun. 10]; Available from: http://ethanolrfa.org/pages/World-FuelEthanol-Production.

SANTANTA, G. C. S., MARTINS, P. F., DE LIMA DA SILVA, N., BATISTELLA, C. B., MACIEL FILHO, R. \& WOLF MACIEL, M. R. 2010. Simulation and cost estimate for biodiesel production using castor oil. Chemical Engineering Research and Design, 88, 5 6, $626-632$.

SARKAR, N., GHOSH, S. S., BANNERJEE, S., AIKAT, K. 2012. Bioethanol production from agricultural wastes: An overview. Renewable energy, $37,1,19-27$. 
SOUZA, O., SCHULZ, M. A., FISCHER, G. A. A., WAGNER, T. M. \& SELLIN, N. 2012. Energia alternativa de biomassa: Bioetanol a partir da casca e da polpa de banana. Revista Brasileira de Engenharia Agrícola e Ambiental, 16, 8, 915 - 921.

WERLE, L. O., MARANGONI, C., STEINMACHER, F. R., ARAÚJO, P. H. H., MACHADO, R. A. F. \& SAYER, C. Uso de aquecimento distribuído em uma coluna de destilação: efeito da perturbação na vazão de alimentação. $4^{\circ}$ PDPETRO, 2007, Campinas, Brasil. 